\title{
Preliminary Taxonomic Studies on Sillago Fish Species of Kollam District of Kerala, India
}

\author{
Dr. Mathews Plamoottil ${ }^{*}$, Sahatrat Muangkhwang \\ *Asst. Professor in Zoology, Government College, Chavara, Kollam, Kerala, India \\ ${ }^{1}$ Researcher, Kasetsart University, Thailand
}

\begin{abstract}
Systematic studies conducted on the Sillago fish species of Kollam district of Kerala. Meristic, metric and other morphometric characters of these fishes were studied and taxonomically analyzed
\end{abstract}

Keywords: Taxonomy, Percoid fishes, Meristic counts, Metric characters

\section{INTRODUCTION}

Sillago species are edible percoid fishes of the family Sillaginidae distributed in saline and brackish waters of India, Southeast Asian countries and Australia. A few are also distributed in water bodies of Africa and Japan They are commonly known as whitings, smelt-whitings, sillaginids, sand borers and sand-smelts.

The genus name was first coined by famous taxonomist Georges Cuvier as a genus for his new species, Sillago acuta. John Richardson placed the genus, along with Sillaginodes and Sillaginopsis in a family. Due to close similarity in appearance and color and also due to overlapping distribution, identification and taxonomic studies of them are hard. So morphology of swim bladder is used for its identification [1, 2]. Many different Sillago species were described and named by various workers were found to be synonyms later. It created confusion in taxonomic studies of Sillago species. Roland McKay [3] of the Queensland Museum published a revision of the family Sillaginidae. It helped to solve the ambiguity which had existed in Sillago systematics. Taxonomic studies conducted on Sillago fishes of India are very rare. It is an endeavor to trace out the systematic details of species of this genus in Kollam district of Kerala.

\section{MATerials AND MeThODS}

Fishes were collected from Ashtamudi Lake at Neendakara, Kollam; they were caught using gill nets and preserved in $10 \%$ formalin. Measurements were made point to point with dial caliper and data recorded to tenth of a millimeter. Methods used are of Jayaram [4, 2]; counts and measurements were made on the left side of specimens. Subunits of head are presented as percentage of head length and head length and proportions of body parts are given as percentage of standard length.

\section{RESULTS AND DISCUSSION}

During the present study two types of Sillago species were collected from Neendakara of Kollam district. After careful observation it was proved that they are of two different species; Sillago sihama Forsskal and Sillago vincenti McKay. Detailed taxonomic studies were conducted on both of these.

\section{SILLAGO SIHAMA FORSSKAL}

Type species name: Atherina sihama

Taxon Authority: Forsskal [5]

Type Locality: Lohaja, Red Sea

Synonyms: Platycephalus shihamas, Bloch \& Scheiner [6]; Sciaena malabarica Bloch \& Scheiner [6], (Tranquebar); Sillago acuta Cuvier [7] (Sea of Indies); Sillago erythraea Cuvier \& Valenciennes [8] (Suez, Red Sea); Sillago malabarica (Cantor) [9].

Common Names: Northern Whiting; sand smell, silver whiting etc.

Regional Name (Malayalam): Kalimeen, Kaaliyodan 


\subsection{Dianosis}

First dorsal fin with XI spines and second dorsal fin with 22 soft rays; anal fin with 21 - 22 soft rays; lateral line scales 74-79; Vertebrae- 34. Two posterior extensions to swim bladder; two anterior extensions extend forward and diverge to terminate on each side of the basioccipital above the auditory capsule, two lateral extensions commence anteriorly; two posterior tapering extensions of swim bladder project into the caudal region, one usually longer than the other; the lateral extensions are normally convoluted and have blind tubules arising along their length. Tip of longest ray of first dorsal fin fairly reach the front base of second dorsal fin.

\subsection{Description}

Body elongate; anterior pre narial profile smooth; dorsal and ventral profiles nearly straight; snout long; eye diameter 40.3- 42.3\% of HL; 2 pairs of nostrils, posterior pair larger, located 1/3 orbit diameter away from orbits. Mouth small, terminal and forwardly placed; upper jaw longer, slightly prominent; lower jaw fit into upper jaw when mouth is closed; numerous minute villiform teeth on upper and lower jaws on its midterminal part. Gill aperture large, lateral, extending to ventral side of head. Two completely separated dorsal fins; first dorsal fin located an internarial distance away from pectoral fin base; second dorsal fin inserted $1 / 2$ of inter orbital width away from first dorsal fin; tip of longest ray of first dorsal fin fairly reach the front base of second dorsal fin; first fin provided with 11 soft spines; it is higher than the second fin, composed of soft spines; two spines longest, others short. Fin membranes of both first and second dorsal fins without distinct color spots in fresh condition; base of second dorsal fin long; it is composed of 22 soft rays, starting at the middle of the body and not extending to caudal fin origin when placed flat; pectoral and ventral fin base provided with small scales; pectoral fin with 14 slender soft rays; ventral fin located a little behind pectoral fin origin,

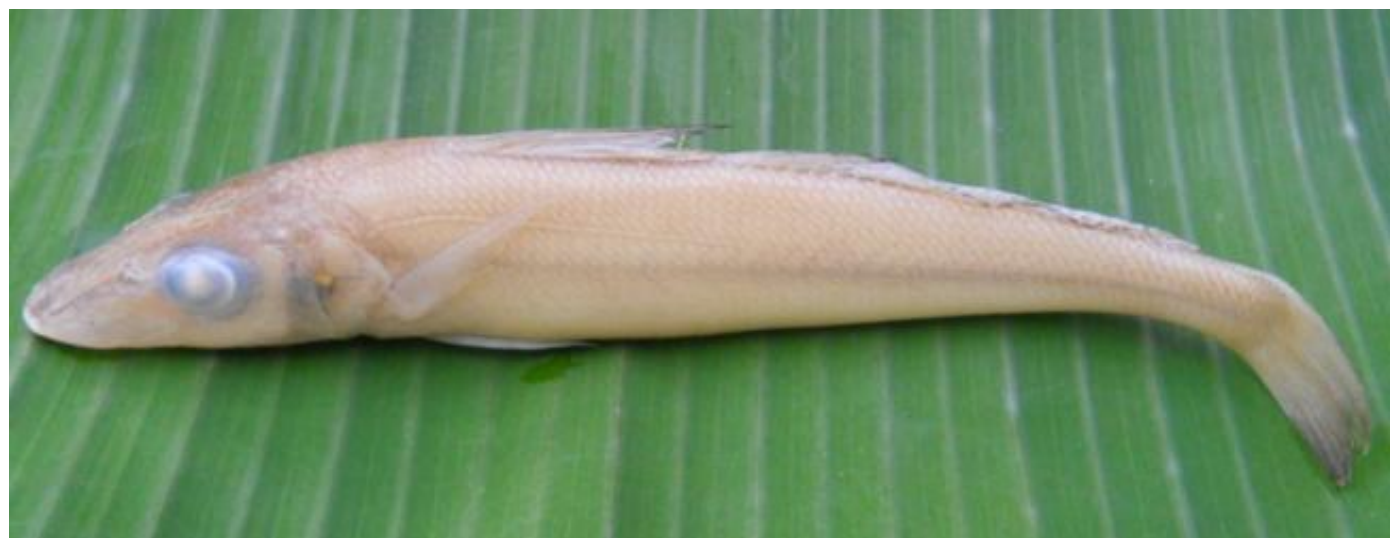

Fig 1. Sillago sihama collected from Neendakara, Kollam

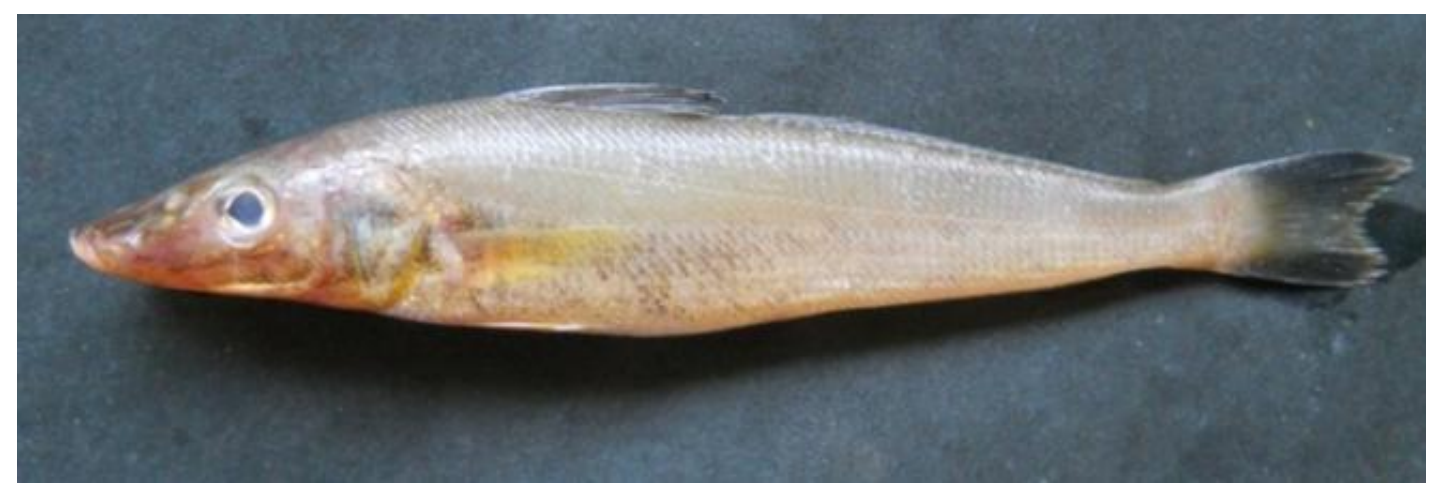

Fig 2. Sillago vincenti collected from Neendakara, Kollam

pointed at its tip; ventral and pectoral fin triangular; one of the ventral fin ray a little longer- half eye diameter longer than rest of ventral fin rays- and never reach vent or anal fin base; origin of anal fin slightly posterior to $2^{\text {nd }}$ dorsal fin; it is with $21-22$ rays, not extending to caudal fin origin when placed flat; caudal peduncle short, depth of caudal peduncle $65.8-72.6 \%$ of its length. Body with ctenoid scales. Lateral line begins above gill aperture and anterior portion of pectoral fin; it is convex on upper lateral region at the anterior part but straight on mid lateral region at its posterior part; it go through upper half of the lateral side for most of its length. 
Preliminary Taxonomic Studies on Sillago Fish Species of Kollam District of Kerala, India

\subsection{Distribution}

Throughout the Indo- Pacific region from Knysna, South Africa to Japan

\subsection{Habitat}

A near shore species that frequently visits estuaries for considerable distances. It has rarely been recorded from freshwater.

Table 1. Meristic counts of Sillago sihama

\begin{tabular}{|c|c|c|}
\hline Sl.No. & Meristic features & Counts \\
\hline 1 & Dorsal fin rays & XI, 22 \\
\hline 2 & Ventral fin rays 5 \\
\hline 3 & Pectoral fin rays & 14 \\
\hline 4 & Anal fin rays & $21-22$ \\
\hline 5 & Caudal fin rays & $18-20$ \\
\hline 6 & Predorsal scales & $27-28$ \\
\hline 7 & Lateral line scales & 5 \\
\hline 8 & Scales between lateral line and dorsal fin & 8.5 \\
\hline 9 & Scales between lateral line and ventral fin & $121 / 2$ \\
\hline 10 & Scales between lateral line and anal fin & 20 \\
\hline 11 & Circum peduncular scales & \\
\hline
\end{tabular}

Table 2. Morphometric measurements of Sillago sihama

\begin{tabular}{|c|c|c|}
\hline Sl. No & Characters & Measurements \\
\hline 1 & Total length (mm) & $238.5-252.5$ \\
\hline 2 & Standard length $(\mathrm{mm})$ & 205.0- 219.0 \\
\hline 3 & Head length $(\mathrm{mm})$ & $59.0-65.0$ \\
\hline \multicolumn{3}{|c|}{$\% \mathrm{SL}$} \\
\hline 3 & Head length & $28.8-29.7$ \\
\hline 4 & Head depth & $11.5-12.3$ \\
\hline 5 & Head width & $12.6-12.8$ \\
\hline 6 & Body depth & $15.5-16.3$ \\
\hline 7 & Predorsal length & $33.3-34.6$ \\
\hline 8 & Post dorsal length & $64.4-65.7$ \\
\hline 9 & Prepectoral distance & $27.4-29.8$ \\
\hline 10 & Prepelvic distance & $28.3-29.8$ \\
\hline 11 & Preanal distance & 53.4- 54.6 \\
\hline 12 & Length of pectoral fin & $14.1-15.1$ \\
\hline 13 & Length of pelvic fin & $14.2-14.6$ \\
\hline 14 & Length of dorsal fin & $19.0-20.3$ \\
\hline 15 & Length of anal fin & $7.3-7.8$ \\
\hline 16 & Length of caudal fin & $15.3-16.3$ \\
\hline 17 & Distance from pelvic to anal fin & $26.4-28.0$ \\
\hline 18 & Distance from anal to caudal fin & $7.4-9.0$ \\
\hline 19 & Length of base of first dorsal fin & $17.6-18.8$ \\
\hline 20 & Length of base of anal fin & $34.2-36.3$ \\
\hline 21 & Length of caudal peduncle & $8.7-9.3$ \\
\hline 22 & Depth of caudal peduncle & $6.1-6.3$ \\
\hline 23 & Width of caudal peduncle & $2.5-2.9$ \\
\hline \multicolumn{3}{|c|}{$\% \mathrm{HL}$} \\
\hline 24 & Head depth & $38.8-42.7$ \\
\hline 25 & Head width & $42.3-44.6$ \\
\hline 26 & Eye diameter & $24.6-27.1$ \\
\hline 27 & Snout length & $40.3-42.3$ \\
\hline 28 & Interorbital width & $16.1-18.8$ \\
\hline 29 & Inter narial width & $17.2-20.0$ \\
\hline 30 & Width of gape of mouth & $13.7-15.2$ \\
\hline
\end{tabular}

\section{SILLAGO VINCENTI McKAY}

Sillago vincenti Mc Kay [10], 378-381, Fig 1 A-C (Kavanad Near Neendakara, Kollam District Kerala, India)

Synonyms: none 


\section{Dr. Mathews Plamoottil \& Sahatrat Muangkhwang}

Common Names: Vincent's Sillago.

Regional Names (Malayalam): Kalimeen, Kaaliyodan

\subsection{Diagnosis}

First dorsal fin with XI spines and second dorsal fin with 20-23 soft rays; anal fin with 23 soft rays. lateral-line scales 77; vertebrae- 34 . Swim bladder with a single posterior extension, a short bulbous projection anteriorly with one to three anterolateral lobate or recurved projections; no tubular extensions anteriorly. Body depth 18.6- 20.0 and head depth 15.0- 15.4 in percentage of standard length. Tip of longest ray of first dorsal fin never reach the base of second dorsal fin.

\subsection{Description}

Body elongate; anterior prenarial profile smooth; 2 pairs of nostrils, posterior one larger, a little in front of eye, 1/3 diameter of eye away from orbit to posterior nares; two pairs of nostrils at the anterior part of eye; mouth small, terminal, forward in position; upper jaw slightly prominent and longer; lower jaw fit into upper jaw when closed. Numerous terminal villiform teeth on midterminal part of upper and lower jaws; pectoral fin base and ventral fin base with small scales; gill aperture large, lateral and extending to ventral side of head.

Two completely separated dorsal fins; first dorsal fin higher than second one; it is located an $1 / 2$ eye diameter away from pectoral base; second dorsal fin inserted a little away ( $1 / 2$ of inter orbital width) from first dorsal fin; tip of longest ray of first dorsal fin never reach the base of second dorsal fin; but smallest fin ray of first dorsal roughly reach second dorsal fin origin; lateral line convex at its origin and straight at caudal peduncle; ventral fin located little behind pectoral fin, pointed at its tip; one of the ventral fin rays is half eye diameter longer than rest of ventral fin rays, never reach vent or anal fin front; first dorsal fin with soft spines; 2 spines longest; others short; base of second dorsal fin long, starting at the middle of the body and not extending to caudal fin origin when placed flat. Origin of anal fin slightly posterior to second dorsal fin, not extending to caudal fin origin when placed flat. Dorsal fins with distinct black spots. Body with ctenoid scales. Colour: Body uniform pale tan coloured, with the second dorsal fin spotted.

Table 3. Meristic counts of Sillago vincenti

\begin{tabular}{|c|c|c|}
\hline Sl.No. & Meristic features & Counts \\
\hline 1 & Dorsal fin rays & XI, 20- 23 \\
\hline 2 & Ventral fin rays & i, 5 \\
\hline 3 & Pectoral fin rays & $16-17$ \\
\hline 4 & Anal fin rays & 23 \\
\hline 5 & Caudal fin rays & 17 \\
\hline 6 & Predorsal scales & 31 \\
\hline 7 & Lateral line scales & 77 \\
\hline 8 & Scales between lateral line and dorsal fin & 6 \\
\hline 9 & Scales between lateral line and ventral fin & 12 \\
\hline 10 & Scales between lateral line and anal fin & 13 \\
\hline 11 & Circum peduncular scales & 20 \\
\hline
\end{tabular}

Table 4. Morphometric characters of Sillago vincenti

\begin{tabular}{|c|c|c|}
\hline 1. No & Characters & Range \\
\hline 1 & Total length (mm) & 200.0 \\
\hline 2 & Standard length (mm) & 175.0 \\
\hline \multicolumn{3}{|c|}{ Percentage of standard Length } \\
\hline 3 & Head length & 31.4 \\
\hline 4 & Head depth & $15.4-15.0$ \\
\hline 5 & Head width & $14.8-15.4$ \\
\hline 6 & Body depth & $18.6-20.0$ \\
\hline 7 & Predorsal length & $35.4-36.6$ \\
\hline 8 & Post dorsal length & $61.1-64.6$ \\
\hline 9 & Prepectoral distance & $31.4-32.6$ \\
\hline 10 & Prepelvic distance & $32.8-33.4$ \\
\hline 11 & Preanal distance & 55.4 \\
\hline 12 & Length of pectoral fin & $15.4-16.8$ \\
\hline 13 & Length of pelvic fin & $14.8-15.4$ \\
\hline
\end{tabular}


Preliminary Taxonomic Studies on Sillago Fish Species of Kollam District of Kerala, India

\begin{tabular}{|c|c|c|}
\hline \hline 14 & Length of dorsal fin & $17.7-19.1$ \\
\hline 15 & Length of anal fin & 7.7 \\
\hline 16 & Length of caudal fin & $13.1-14.3$ \\
\hline 17 & Distance from pelvic to anal fin & $36.7-26.8$ \\
\hline 18 & Distance from anal to caudal fin & $17.7-18.8$ \\
\hline 19 & Length of base of first dorsal fin & $29.1-32.0$ \\
\hline 20 & Length of base of anal fin & $8.9-11.4$ \\
\hline 21 & Length of caudal peduncle & $6.6-7.4$ \\
\hline 22 & Depth of caudal peduncle & $3.1-3.7$ \\
\hline 23 & Width of caudal peduncle & $47.3-48.2$ \\
\hline 24 & Percentage of head length & $44.5-45.4$ \\
\hline 25 & Head depth & $23.6-27.3$ \\
\hline 26 & Head width & 40.0 \\
\hline 27 & Eye diameter & $16.3-21.8$ \\
\hline 28 & Snout length & 15.4 \\
\hline 30 & Interorbital width & $14.5-16.4$ \\
\hline
\end{tabular}

Table 5. Morphometric differences between Sillago sihama and S. vincenti

\begin{tabular}{|c|c|c|c|}
\hline Sl. No & Characters & S. sihama & S. vincenti \\
\hline \multicolumn{4}{|c|}{$\% \mathrm{SL}$} \\
\hline 1 & Head length & $28.8-29.7$ & 31.4 \\
\hline 2 & Head depth & $11.5-12.3$ & $15.0-15.4$ \\
\hline 3 & Head width & $12.6-12.8$ & $14.8-15.4$ \\
\hline 4 & Body depth & $15.5-16.3$ & $18.6-20.0$ \\
\hline 5 & Predorsal length & 33.3- 34.6 & 35.4- 36.6 \\
\hline 6 & Post dorsal length & $64.4 \quad 65.7$ & $61.1-64.6$ \\
\hline 7 & Prepectoral distance & $27.4-29.8$ & 31.4- 32.6 \\
\hline 8 & Prepelvic distance & $28.3-29.8$ & $32.8-33.4$ \\
\hline 9 & Preanal distance & 53.4- 54.6 & 55.4 \\
\hline 10 & Length of pectoral fin & $14.1-15.1$ & $15.4-16.8$ \\
\hline 11 & Length of pelvic fin & $14.2-14.6$ & $14.8-15.4$ \\
\hline 12 & Length of dorsal fin & $19.0-20.3$ & $17.7-19.1$ \\
\hline 13 & Length of anal fin & $7.3-7.8$ & 7.7 \\
\hline 14 & Length of caudal fin & $15.3-16.3$ & $13.1-14.3$ \\
\hline 15 & Distance from pelvic to anal fin & $26.4-28.0$ & $23.7-26.8$ \\
\hline 16 & Length of base of anal fin & $34.2-36.3$ & $29.1-32.0$ \\
\hline 17 & Length of caudal peduncle & $8.7-9.3$ & 8.9- 11.4 \\
\hline 18 & Depth of caudal peduncle & $6.1-6.3$ & $6.6-7.4$ \\
\hline \multirow[t]{2}{*}{19} & Width of caudal peduncle & $2.5-2.9$ & $3.1-3.7$ \\
\hline & \multicolumn{3}{|c|}{$\% \mathrm{HL}$} \\
\hline 20 & Head depth & $38.8-42.7$ & $47.3-48.2$ \\
\hline 21 & Head width & $42.3-44.6$ & $44.5-\quad 45.4$ \\
\hline 22 & Snout length & $40.3-42.3$ & 40.0 \\
\hline 23 & Inter narial width & $17.2-20.0$ & 15.4 \\
\hline 24 & Width of gape of mouth & $13.7-15.2$ & $14.5-16.4$ \\
\hline
\end{tabular}

Geographical Distribution: East and west coast of India

Remarks: This species is very similar in external morphology to Sillago sihama. A dissection of the posterior part of the swim bladder is required for field identification.

\section{Conclusion}

Order Perciformes is the most diversified of all fish orders; its classification is controversial since many families are similar and are not easily definable in terms of common shared derived characters [2, 11]. Sillago species are edible percoid fishes. 31 Sillago species were reported from various parts of world. Sillago sihama and S. vincenti are commonly found in south Indian waters. They are indistinguishable by direct observation. But both these show distinct differences in morphometric characters and in the structure of swim bladder. Color differences can also be noticed in both. Fins of $S$. sihama is hyaline but that of $S$. vincenti is colored. Fins of Sillago vincenti is with dark spots but 
plain in S. sihama. The latter one is an elongated species compared to $S$. vincenti. Many of the morphometric measurements show considerable differences between these two Sillago species. Tip of longest dorsal fin ray of first dorsal fin fairly reach front base of second dorsal fin in Sillago sihama but it never reach in $S$. vincenti. As shown in Table 5, S. sihama and S. vincenti shows morphological differences in 24 characters. Relevant taxonomic studies conducted on the Sillago fishes of Kerala are rare. The present study also revealed that Sillago population has also been declined greatly in last few years. It is due to pollution and indiscriminate and over fishing [12, 13].

Inventorying and monitoring of biodiversity of a biogeographically significant territory is a pre requisite for biodiversity conservation. Conservation efforts require scientific documentation of bioresources along with details on their distribution and status $[14,15,16]$. This requires inventory and systematic studies of the fishes. A detailed study on the different aspects of taxonomy of fishes is helpful in the correct identification and to search for the presence of new species. It emphasizes the need of taxonomical studies on Sillago and all other species. It is expected that more relevant taxonomic studies may be conducted on the Sillago fishes in near future.

\section{ACKNOWLEDGEMENTS}

Both authors acknowledge the anonymous reviewers comments of which helped to improve the manuscript. The first author acknowledges Principal, Baby John Memorial Govt. College Chavara for providing necessary facilities.

\section{REFERENCES}

[1] Talwar PK. \& Jhingran A. Inland fishes of India and adjacent countries. Oxford and IBH publishing Co., New Delhi, 1991, 250- 286.

[2] Jayaram KC. Fresh water fishes of the Indian region. Narendra publishing House, Delhi, 2010, $292 \mathrm{pp}$

[3] McKay RJ. A revision of the fishes of the family Sillaginidae, memoirs of Quensland Museum, 1985, 23 (1): 1-73.

[4] Jayaram KC. Fundamentals of fish taxonomy. Narendra publishing House, Delhi, 2002, 53-65.

[5] Forsskål P. Descriptiones animalium; avium, amphibiorum, piscium, insectorum, vermium; quae in itinere orientali observavit Petrus Forskal-Hauniae. Post mortem auctoris edidit Carsten Niebuhr, Copenhagen, 1775, 164 pp.

[6] Bloch ME. \& Schneider JG. M.E. Blochii Systema Ichthyologiae iconibus ex illustratum. Post obitum auctoris opus inchoatum absolvit, correxit, interpolavit J.G. Schneider, Saxo, Berolini, $1801,584 \mathrm{pp}$

[7] Cuvier G. Le règne animal distribué d'après son organisation, pour servir de base à l'histoire naturelle des animaux et d'introduction a l'anatomie compare. Poissons 2. Deterville, Paris. 1817, $532 \mathrm{pp}$.

[8] Cuvier G \& Valenciennes A. Histoire naturelle des poisons. Tome troisième. Suite du Livre troisième. Des percoïdes à dorsale unique à sept rayons branchiaux et à dents en velours ou en cardes. 3. Paris, Levrault, Strasbourg. 1829.500 pp.

[9] Cantor TE. Catalogue of the Malayan Fishes, Journal of Asiatic Society of Bengal, 1849,18 (2): 983- 1443

[10] Mc Kay RJ. The fishes of the family Sillaginidae from India with a description of a new species; Journal of Marine Biology Association of India, 1980, 18: 375- 385.

[11] Plamoottil M. Systematic accounts on percoid fishes of Travancore. International Journal of Research in Environmental Science, 2016, 2 ( 5): 12-23

[12] Plamoottil M \& Abraham N P. Indegenous fishing methods of manimala River. Journal of Advanced Zoology, 2013, 34 (2): 92- 102.

[13] Plamoottil M \& Win T. On some destructive fishing methods of Central Travancore of Kerala, India. Journal of Zoological and Bioscience Research, 2017, 4 (1): 6-12

[14] Easa PS. \& Shaji CP. Fresh water fish diversity in Kerala part of Nilgiri Biosphere Reserve. Current science, 1997, 73(2): 180-182.

[15] Easa PS. \& Shaji CP. Biodiversity documentation for Kerala. Part 8, KFRI, Peechi, 2003, $127 \mathrm{pp}$.

[16] Easa, PS. \& Basha SC A survey on the habitat and distribution of stream fishes in the Kerala part of Nilgiri Biosphere Reserve, KFRI research report No. 104. Kerala Forest research Institute, Peechi, 1995. 